Bull. Chem. Soc. Ethiop. 2020, 34(2), 323-334.

ISSN 1011-3924

(c) 2020 Chemical Society of Ethiopia and The Authors

Printed in Ethiopia

DOI: https://dx.doi.org/10.4314/bcse.v34i2.10

\title{
SYNTHESIS OF CUO-NPS BY SIMPLE WET CHEMICAL METHOD USING VARIOUS DICARBOXYLIC ACID SALTS AS PRECURSORS: SPECTRAL CHARACTERIZATION AND IN-VITRO BIOLOGICAL EVALUATION
}

\author{
Hajira Rehman ${ }^{1}$, Zulfiqar Ali $^{2}$, Abdul Qadir ${ }^{3}$, M. Hassan Farooq ${ }^{2 *}$, Ahmed Shuaib ${ }^{2}$, Asmat \\ Zahra $^{4}$, Tanzeela Shahzady ${ }^{3}$ and Habib Hussain ${ }^{5}$ \\ ${ }^{1}$ Department of Chemistry, University of Sahiwal, Sahiwal, Pakistan \\ ${ }^{2}$ Department of Basic Sciences \& Humanities University of Engineering \& technology Lahore \\ KSK Campus, Pakistan \\ ${ }^{3}$ Department of Chemistry Lahore Garrison University, Lahore, Pakistan \\ ${ }^{4}$ Institute of Chemistry, University of The Punjab, Lahore, Pakistan \\ ${ }^{5}$ Department of Basic Sciences \& Humanities University of Engineering \& Technology Lahore \\ Narowal Campus, Pakistan
}

(Received September 9, 2019; Revised September 28, 2020; Accepted October 1, 2020)

\begin{abstract}
In this study, a simple chemical reduction method was employed to synthesize CuO-NPs. Various dicarboxylic acids were converted into $\mathrm{Cu}$ (II) salt of dicarboxylic acid which were used as precursors. NPs were produced by reducing precursors with $\mathrm{NaBH}_{4}$. Characteristics of synthesized NPs were investigated by using important analytical techniques including Fourier transform infrared (FTIR) spectroscopy, X-ray diffraction (XRD), thermo gravimetric analysis (TGA) and scanning electron microscopy (SEM). Developed NPs were investigated for their antibacterial activity against a range of bacterial strains by employing agar well diffusion method. CuO-NPs exhibited good to moderate activity against E-Coli, B. Subtilis and poor activity against $K$. pneumonia and Methicillin-resistant Staphylococcus aureus (MRSA). It was found that amongst all experienced compounds sample 2 showed good activity with minimum inhibition concentration (MIC) $10 \mu \mathrm{g} / \mathrm{mL}$ (zone of inhibition: $22 \pm 0.12 \mathrm{~mm}$ ) while sample 3 showed poor activity with MIC $40 \mu \mathrm{g} / \mathrm{mL}$ (zone of inhibition: $8.0 \pm 0.18$ $\mathrm{mm})$.
\end{abstract}

KEY WORDS: CuO-NPs, Dicarboxylic acids, Sodium borohydride, Antibacterial study

\section{INTRODUCTION}

Now a day's modern research is revolving around nanotechnology because nanoparticles have unique catalytic [1] and bio-medical applications [2,3]. CuO-NPs are of great interest than other metal NPs due to its low cost and easy availability. Copper oxide nanomaterials have been developed substantially in recent years due to its low cost fabrication and good electrochemical properties. Copper oxides NPs are used for gas sensors [4], photovoltaic solar cell [5, 6], photo electrochemical cell $[7,8]$ and electro-chromic coatings [9].

Metal oxide NPs mainly dragged the attention of researchers due to their medicinal applications. Metal oxides exhibited excellent antimicrobial and antifungal activities against various organisms [10-12]. Metallic NPs have immense surface area and this surface area and particle size play a key role in medicinal, catalytic activities and photocatalytic degradation [13], that is why comparison of metallic NPs surface area with conventional materials have been intensely investigated [14].

Now a day there is a common use of antibacterial agents in various fields including, food packaging, textile industry, water disinfection and medicine [15]. Over dosing of antibiotics has resulted in increased bacterial strains having antibiotic resistant genes. In order to resolve this problem, a great deal of research has been done. NPs exhibit a range of potentially useful

*Corresponding author. E-mail: mhfarooq@uet.edu.pk

This work is licensed under the Creative Commons Attribution 4.0 International License 
applications for pharmaceutical purposes. In last few decades, nanotechnology has great interest in evaluating activity of nano-scale metals as antimicrobial agents.

Antimicrobial study of different metallic NPs such as alumina [16], silver [17], iron [18, 19], gold [20, 21], magnesium [22, 23], titanium [24], and zinc oxide [25] were investigated on large scale. Although tremendous efforts have been done to utilize NPs as an antibacterial agent, still we are not able to develop ideal metallic NPs with proficient activity. In this research an effort is made to find out a quick and easy method to synthesize CuO-NPs. Dicarboxylic acid salts are used as precursors to synthesize the target materials and their antimicrobial activities were investigated against different pathogenic strains of bacteria.

\section{EXPERIMENTAL}

\section{Synthesis of CuO-NPs by using copper(II) succinate precursor}

By following procedure adopted by Arunachalam et al. [26], $2.5 \mathrm{~g}$ of $\mathrm{CuSO}_{4} \cdot 5 \mathrm{H}_{2} \mathrm{O}$ was taken and dissolved in distilled water $(20 \mathrm{~mL})$ in a beaker equipped with magnetic stirrer to form a homogeneous mixture. In order to prepare sodium succinate, $0.80 \mathrm{~g}$ of sodium hydroxide and $1.18 \mathrm{~g}$ succinic acid were mixed in a beaker having $10 \mathrm{~mL}$ distilled water. Prepared sodium succinate was introduced in copper sulfate solution drop wise under continues magnetic stirring. Resulting solution was magnetically stirred for $50 \mathrm{~min}$ and a green precipitate of copper(II) succinate was collected which was further centrifuged, washed several times with ethanol and then product was dried.

In order to make final product, solution of $\mathrm{NaBH}_{4}$ was prepared by adding $1.3 \mathrm{~g}$ of it in 10 $\mathrm{mL}$ distilled water. $1.80 \mathrm{~g}$ copper succinate dissolved in $10 \mathrm{~mL}$ distilled water and $\mathrm{NaBH}_{4}$ solution was added drop wise to this solution with stirring. Reaction mixture was kept in the ultrasonic bath for $60 \mathrm{~min}$. Formation of copper oxide nanoparticles was confirmed by turning green colored solution instantly into black upon addition of $\mathrm{NaBH}_{4}$ solution [26]. Copper oxide nanoparticles thus formed, filtered and dried.

\section{Synthesis of CuO-NPs by using copper(II) adipiate precursor}

Solution of $\mathrm{CuSO}_{4} .5 \mathrm{H}_{2} \mathrm{O}$ was prepared by dissolving $2.5 \mathrm{~g}$ of it in distilled water in a beaker equipped with magnetic stirrer. In another beaker, $0.80 \mathrm{~g}$ of sodium hydroxide accurately weighed and $1.46 \mathrm{~g}$ of adipic acid in $10 \mathrm{~mL}$ distilled water were mixed to form sodium adipiate solution. Sodium adipiate thus formed was added drop wise to copper sulphate solution under stirring which was continued for $50 \mathrm{~min}$ and at end a dark green precipitate of copper(II) adipiate was obtained. These precipitates were washed followed by centrifugation and then dried. In the $2^{\text {nd }}$ step, $1.3 \mathrm{~g}$ of $\mathrm{NaBH}_{4}$ dissolved in $10 \mathrm{~mL}$ distilled water and introduced drop wise into copper(II) adipiate solution prepared by adding $2.07 \mathrm{~g}$ of this salt into distilled water of volume $10 \mathrm{~mL}$ and solution was kept in ultrasonic bath for 1 hour. When $\mathrm{NaBH}_{4}$ solution was added dark green colored solution instantly turned dark brown which indicated the formation of CuO-NPs. Nanoparticles thus formed, filtered and dried.

\section{Synthesis of CuO-NPs by using copper(II) malonate precursor}

Copper sulfate solution was prepared by taking $2.5 \mathrm{~g}$ of it in $20 \mathrm{~mL}$ distilled water in a beaker equipped with magnetic stirrer to form a homogeneous mixture. In order to prepare sodium malonate, $0.80 \mathrm{~g}$ of sodium hydroxide and $1.04 \mathrm{~g}$ malonic acid was dissolved in $10 \mathrm{~mL}$ distilled water in a beaker. Sodium malonate thus formed was added in copper sulfate solution under constant stirring. Magnetic stirring of solution continued for 40-50 min and a green precipitate of copper(II) malonate was collected, washed, centrifuged and dried. 
$\mathrm{NaBH}_{4}$ solution and solution of copper(II) malonate were prepared separately by dissolving $1.3 \mathrm{~g}$ and $1.65 \mathrm{~g}$ of both materials, respectively, in $10 \mathrm{~mL}$ distilled water. Then two solutions were mixed into each other drop wise and resulting solution was kept in ultrasonic bath for 60 min. Upon addition of sodium borohydride, green colored solution turned black, which indicated the formation of CuO-NPs. Nanoparticles thus formed, filtered and dried.

Experimental procedure of antimicrobial activity

Antimicrobial study of synthesized NPs was based on following steps:

Preparation of the test compound

$2 \mathrm{mg}$ of NPs (each sample separately) were dissolved in $1 \mathrm{~mL}$ of ethanol which was further diluted of varying concentrations, i.e. $(0.2 \mathrm{mg} / 0.1 \mathrm{~mL}, 0.02 \mathrm{mg} / 0.1 \mathrm{~mL}$, and $0.002 \mathrm{mg} / 0.1 \mathrm{~mL})$ for microbiological assays.

\section{LB broth preparation}

LB broth is prepared (without agar), shifted in five test tubes, each containing $5 \mathrm{~mL}$ broth and autoclaved. Inoculation of five bacterial strains were done in these test tubes and placed on shaker for 24 hours.

Preparation of agar plates and microbiological assays

Severe sterilized and aseptic conditions were maintained and procedure was done in laminar airflow. Applying the agar plate diffusion technique test organisms was grown in LB nutrient agar medium. The composition of the medium was $(\mathrm{g} / \mathrm{L})$ tryptone $(1.0 \mathrm{~g})$, yeast extract $(0.5 \mathrm{~g})$, sodium chloride $(0.5 \mathrm{~g})$; agar $(1.5-2 \mathrm{~g})$ and water $(100 \mathrm{~mL})$. CuO-NPs synthesized by three different precursors were tested according to pre mentioned concentration by dissolving in ethanol, while ethanol itself was used as control for comparison.

$\mathrm{N}$-agar media was autoclaved and $25-30 \mathrm{~mL}$ of the media was added into the $9 \mathrm{~cm}$ diameter Petri-dish, allowed to solidify and then one $\mathrm{ml}$ bacterial suspension was transferred/plate incubated at $27{ }^{\circ} \mathrm{C}$ for 24 hours. The wells were made in the plates with the help of autoclaved pasture pipette and then it was filled with the synthesized CuO-NPs solution. The $100 \mu \mathrm{g} / \mathrm{mL}$ concentration of NPs was used and activity was determined by measuring the inhibition zone.

\section{RESULTS AND DISCUSSION}

\section{IR studies of $\mathrm{CuO} N P S$}

IR spectrum of synthesized $\mathrm{CuO}$ NPs by using malonic acid, succinic acid and adipic acid precursor were recorded. Since water is adsorbed on metal surface in nanoparticles that is why two characteristic absorption peaks were expected, one of them above $3000 \mathrm{~cm}^{-1}$ which was not prominent in malonic acid precursor spectrum and second peak at $1119.00 \mathrm{~cm}^{-1}$. In this spectrum $1^{\text {st }}$ peak was not prominent but $2^{\text {nd }}$ peak was quit prominent. This $2^{\text {nd }}$ prominent peak might be due to $-\mathrm{OH}$ twisting frequency. In succinic acid precursor spectrum two characteristic absorption peaks were recorded at 3261.20 and $1113.00 \mathrm{~cm}^{-1}$ which might be due to $-\mathrm{OH}$ stretching and twisting frequencies respectively due to adsorbed water molecules. Similarly adipic acid precursor spectrum also exhibited these two characteristic absorption peaks at 3403.00 and $1120.40 \mathrm{~cm}^{-1}$. Literature proved that $\mathrm{M}-\mathrm{O}$ stretching and twisting vibrations were seen beneath $1000 \mathrm{~cm}^{-1}$ so IR spectra bellows this range of our interest. Crest in malonic acid 
precursor spectrum at $620.32 \mathrm{~cm}^{-1}$ is considered due to $\mathrm{Cu}-\mathrm{O}$ str-frequency [27] which is a decent proof of development of $\mathrm{Cu}-\mathrm{O}$ linkage in synthesized nanoparticles. Similarly in other two spectra, peaks recognized at $612.33 \mathrm{~cm}^{-1}$ and $598.16 \mathrm{~cm}^{-1}$, respectively, are associated with $\mathrm{Cu}-\mathrm{O}$ stretching [28].

XRD studies of $\mathrm{CuO} N P$ :

Powder XRD analysis of sample 1

XRD analysis of synthesized NPs was carried on X-ray powder diffractometer under $45 \mathrm{kV} / 40$ $\mathrm{mA} \mathrm{X}$-ray, $2 \theta{ }^{\circ}$ scanning mode, fixed monocharomator with a range from $2 \theta{ }^{\circ}=10$ to 90 with a step of 0.02 degree for a period of $30 \mathrm{~min}$ as shown in Figure 1. Eight peaks were selected and miller indices were calculated for them as shown in Table 1.

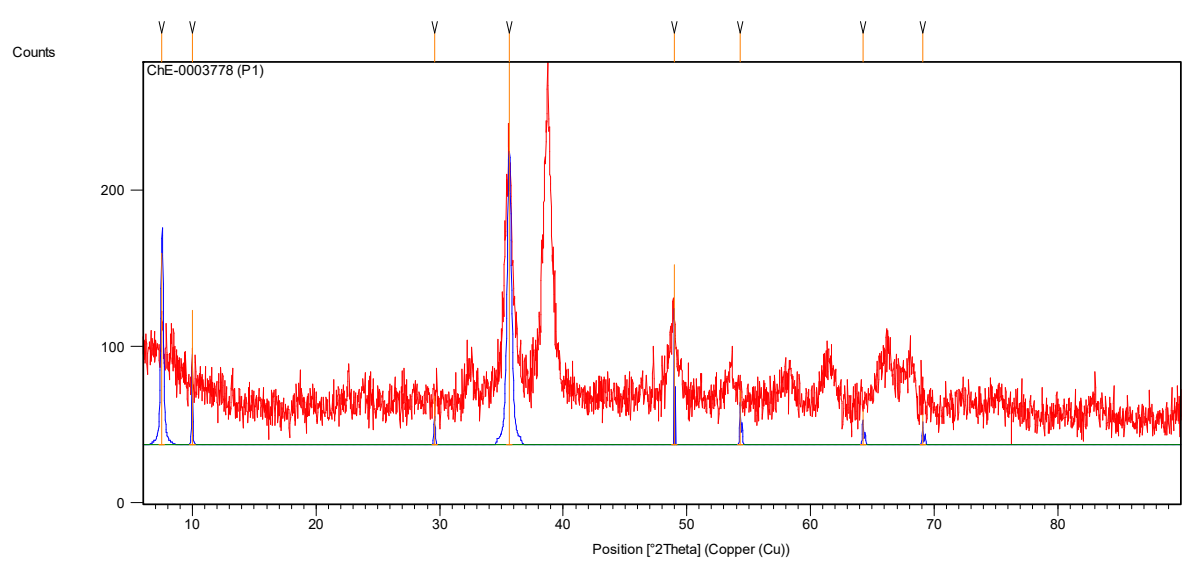

Figure 1. XRD spectra of NPs (Sample 1).

Table 1. Calculation of miller indices through XRD diffraction pattern.

\begin{tabular}{|c|c|c|c|c|c|c|c|}
\hline $2 \theta / 0$ & $\theta /{ }^{0}$ & $\operatorname{Sin}^{2} \theta$ & \begin{tabular}{c}
$1 \times \frac{\operatorname{Sin}^{2} \theta}{\operatorname{Sin}^{2} \theta_{\min }}$ \\
\hline 7.5487
\end{tabular} & $\begin{array}{c}2 \times \operatorname{Sin}^{2} \theta \\
\operatorname{Sin}^{2} \theta_{\min }\end{array}$ & $\begin{array}{c}3 \times \operatorname{Sin}^{2} \theta \\
\operatorname{Sin}^{2} \theta_{\min }\end{array}$ & $\begin{array}{c}\text { Whole } \\
\text { integers }\end{array}$ & $H k l$ \\
\hline 9.9686 & 4.9842 & 0.00433 & 1 & 2 & 3 & 3 & 111 \\
\hline 29.5423 & 14.7711 & 0.00758 & 1.7509 & 3.5013 & 5.1939 & 5 & 210 \\
\hline 36.9967 & 18.4983 & 0.10066 & 23.2363 & 46.4456 & 69.7091 & 70 & 653 \\
\hline 49.5321 & 24.7660 & 0.17547 & 40.4893 & 80.9786 & 121.468 & 121 & 766 \\
\hline 55.3230 & 27.6615 & 0.21552 & 49.7736 & 99.5472 & 149.3208 & 149 & 876 \\
\hline 64.0010 & 32.0005 & 0.28082 & 64.8545 & 130.1477 & 194.5635 & 194 & 987 \\
\hline 69.6703 & 34.8351 & 0.32628 & 75.3533 & 150.7066 & 226.0599 & 226 & 998 \\
\hline
\end{tabular}

Miller indices of synthesized nanoparticles were calculated for by using malonic acid precursor from selected peaks as shown in Table 1 . Calculated and reported pattern of $\mathrm{CuO}$ nanoparticles was compared by peak search method and presented great resemblance. All major peaks at positions $2 \theta /{ }^{\circ} 7.5487,9.9686,29.5423,36.9967,49.5321,55.3230,64.0010,69.6703$ have miller indices $111,210,542,653,766,876,987,998$, respectively, which are the characteristics of $\mathrm{CuO}$ scan pattern. 
Material parameters were calculated with the help of $2 \theta /{ }^{\circ}$ values and grain size was found to be in range of $9.0561 \mathrm{~nm}$ to at $2 \theta /^{\circ}=7.5487$ to $33.9828 \mathrm{~nm}$ at $2 \theta /^{\circ}=69.6703$.

\section{Powder XRD analysis of sample 2}

X-ray powder diffraction analysis of sample 2 was carried out by following same conditions and parameters which were employed for sample 1 . For this sample total seven peaks were targeted and calculated their miller indices as shown in Table 2.

Table 2. Calculation of miller indices through XRD diffraction Pattern.

\begin{tabular}{|c|c|c|c|c|c|c|c|}
\hline $2 \theta /{ }^{0}$ & $\theta /^{\circ}$ & $\operatorname{Sin}^{2} \theta$ & $\begin{array}{l}1 \times \frac{\operatorname{Sin}^{2} \theta}{\operatorname{Sin}^{2} \theta_{\min }}\end{array}$ & $\begin{array}{l}\text { 2x } \frac{\operatorname{Sin}^{2} \theta}{\operatorname{Sin}^{2} \theta_{\min }} \\
x^{2}\end{array}$ & $\begin{array}{l}3 \times \frac{\operatorname{Sin}^{2} \theta}{\operatorname{Sin}^{2} \theta_{\min }}\end{array}$ & $\begin{array}{l}\text { Whole } \\
\text { integers }\end{array}$ & $\mathrm{Hkl}$ \\
\hline 6.5506 & 3.2753 & 0.00326 & 1 & 2 & 3 & 3 & 111 \\
\hline 10.8075 & 5.4037 & 0.00886 & 2.7177 & 5.4354 & 8.1531 & 8 & 220 \\
\hline 13.6687 & 6.8343 & 0.01416 & 4.3435 & 8.6870 & 13.0305 & 13 & 320 \\
\hline 24.4260 & 12.2130 & 0.04475 & 13.7269 & 27.4538 & 41.1809 & 41 & 540 \\
\hline 25.6642 & 12.7321 & 0.04857 & 14.8987 & 29.7974 & 44.6961 & 45 & 630 \\
\hline 33.0136 & 16.5068 & 0.08072 & 24.7607 & 49.5214 & 74.2821 & 74 & 750 \\
\hline 44.0968 & 22.0484 & 0.14091 & 43.2239 & 86.4478 & 129.6717 & 130 & 970 \\
\hline
\end{tabular}

The miller indices of synthesized nanoparticles by using succinic acid precursor have been calculated from selected peaks as shown in Table 2. The calculated pattern of $\mathrm{CuO}$ nanoparticles was compared with reported patterns (present in the library) by peak search method and showed great resemblance. All the major peaks at positions $2 \theta /^{\circ} 6.5506,10.8075,13.6687,24.4260$, 25.6642, 33.0136, 44.0968 have miller indices 111, 220, 320, 540, 630, 750, 970, respectively, which are the characteristics of $\mathrm{CuO}$ scan pattern.

After performing calculations, grain size was found to be in the range of $9.0502 \mathrm{~nm}$ at $2 \theta /^{\circ}=$ 6.5506 to $13.9067 \mathrm{~nm}$ at $2 \theta /^{\circ}=25.6642$.

\section{Powder XRD analysis of sample 3}

Sample 3 was also by following same conditions and parameters of X-ray diffractometer which were employed for sample 1 . For this sample 8 prominent peaks were taken for calculating their miller indices, data presented in Table 3.

Table 3. Calculation of miller indices through XRD diffraction pattern.

\begin{tabular}{|c|c|c|c|c|c|c|c|}
\hline $2 \theta /^{0}$ & $\theta /{ }^{0}$ & $\operatorname{Sin}^{2} \theta$ & $\begin{array}{c}1 \times \operatorname{Sin}^{2} \theta \\
\operatorname{Sin}^{2} \theta_{\min }\end{array}$ & $\begin{array}{c}2 \times \operatorname{Sin}^{2} \theta \\
\operatorname{Sin}^{2} \theta_{\min }\end{array}$ & $\begin{array}{c}3 \times \operatorname{Sin}^{2} \theta \\
\operatorname{Sin}^{2} \theta_{\min }\end{array}$ & $\begin{array}{c}\text { Whole } \\
\text { integers }\end{array}$ & $H k l$ \\
\hline 7.6370 & 3.8185 & 0.00443 & 1 & 2 & 3 & 3 & 111 \\
\hline 12.8423 & 6.4211 & 0.01250 & 2.8216 & 5.6432 & 8.4648 & 8 & 220 \\
\hline 14.5882 & 7.2941 & 0.01611 & 3.6590 & 7.8181 & 10.9772 & 11 & 311 \\
\hline 19.0634 & 9.5317 & 0.02742 & 6.2272 & 12.4545 & 18.6818 & 19 & 331 \\
\hline 21.4065 & 10.7032 & 0.03449 & 7.8386 & 15.6772 & 23.5159 & 24 & 422 \\
\hline 31.6605 & 15.8302 & 0.07441 & 16.7968 & 33.5936 & 50.3904 & 50 & 543 \\
\hline 47.6014 & 23.8007 & 0.16285 & 36.7607 & 73.5214 & 110.2821 & 110 & 765 \\
\hline 62.1894 & 31.0947 & 0.26672 & 60.2076 & 120.4152 & 180.6228 & 181 & 986 \\
\hline
\end{tabular}

Miller indices of synthesized nanoparticles by using Adipic acid precursor have been calculated from selected peaks. Calculated pattern of $\mathrm{CuO}$ nanoparticles was matched with reported patterns (present in the library) by peak search method and showed great resemblance. All main peaks at positions $2 \theta /{ }^{\circ} 7.6370,12.8423,14.5882,19.0634,21.4065,31.6605,47.6014$, 
62.1894 have miller indices $111,220,311,331,422,543,765,986$, respectively, which are the characteristics of $\mathrm{CuO}$ scan pattern.

In this sample grain size was found to be $11.2723 \mathrm{~nm}$ at $2 \theta /^{\circ}=31.6605$ to $13.7549 \mathrm{~nm}$ at $2 \theta /^{0}=19.0634$. X- ray diffraction analysis showed that $\mathrm{CuO}$ NPs were synthesized with varying sizes by using three different precursors. The smallest particle sizes with highest surface area were recorded for those NPs (sample 2) which were synthesized by using succinic acid as a precursor.

\section{SEM analysis}

Sample 1. SEM image shown in Figure 2 was utilized in order to reveal surface morphology of $\mathrm{CuO}$ nanoparticles synthesized in this project recorded at $25 \mathrm{kx}$ (Figure 2a) and $10 \mathrm{kx}$ (Figure 2b) magnifications respectively. Both figures belong to same sample but with different magnifications.

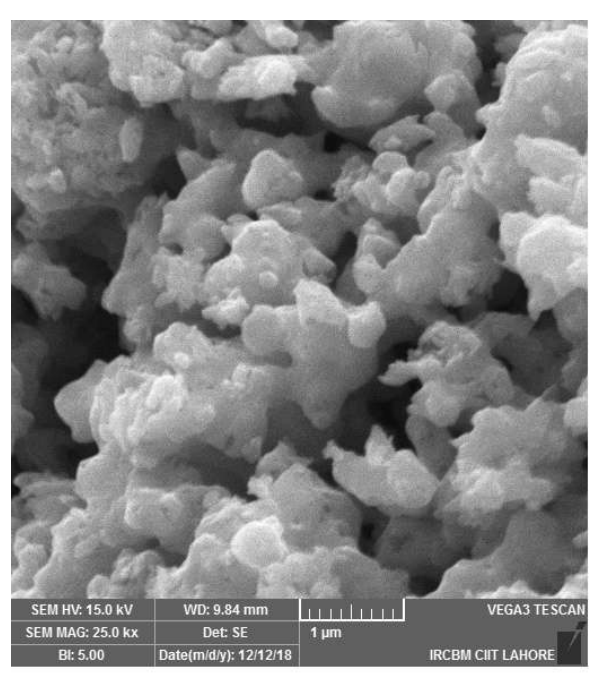

Fig (a)

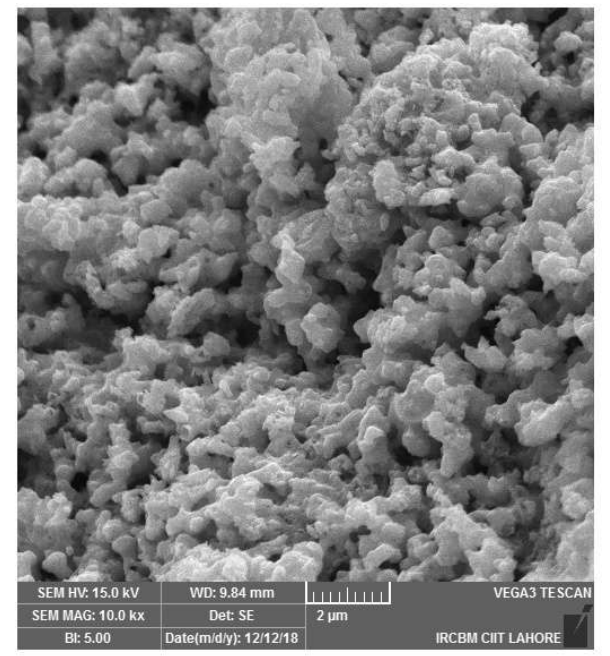

Fig (b)

Figure 2. SEM image CuO NPs from malonic acid as precursor.

It is obvious from above diagram that large number of $\mathrm{CuO}$ nanosphere agglomerates with a uniform size. Similarly non-agglomerated random shape particles aggregate to give a flower shape structure of synthesized NPs.

Sample 2. Surface morphology of $\mathrm{CuO}$ nanoparticles recorded at various magnifications through SEM analysis are shown in Figure 3.

It is obvious from above SEM images that particles are spherical and dispersed in a good manner having a properly and well defined homogeneous crystalline structure. SEM is also showing good tendency of these particles for agglomerations. A regular polyhedron shape for the CuO-NPs can be seen in above SEM images. Island growth of firmly packed spherical arrangement is also observed clearly. However there are some regions were big nanoparticles are surrounded by smaller nanoparticles. Similar CuO-NPs SEM images were taken into record and reported [29]. 


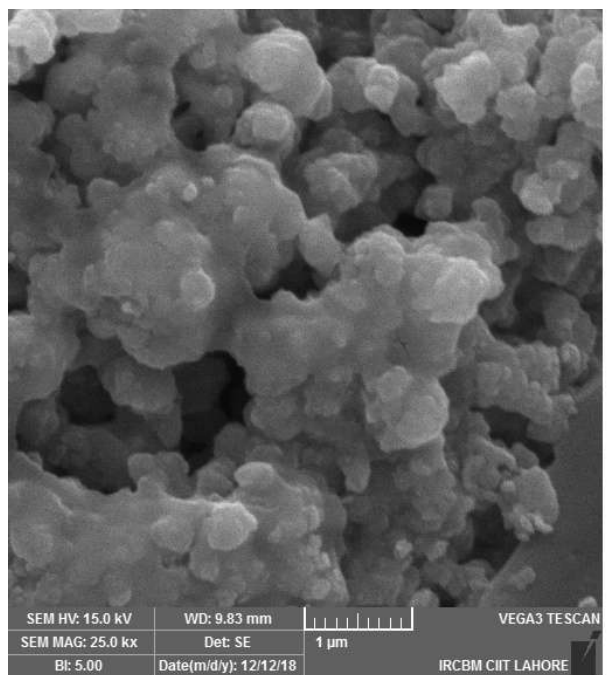

Fig (a)

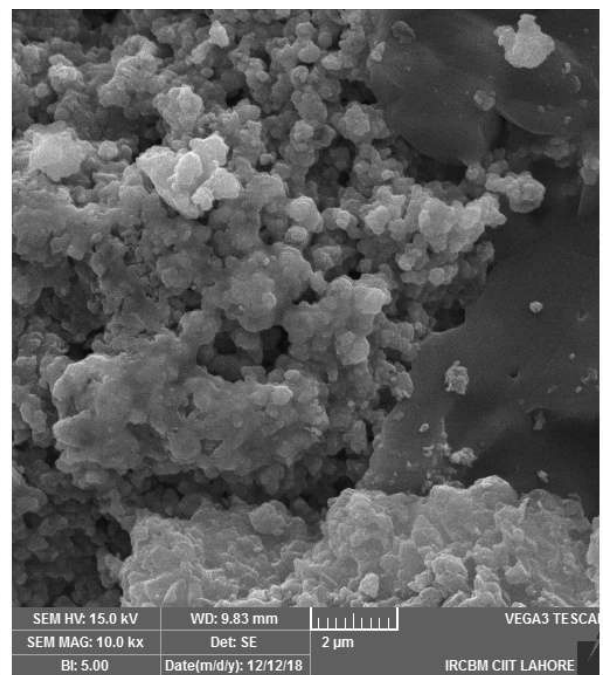

Fig (b)

Figure 3. SEM image $\mathrm{CuO}$ NPs from succinic acid as a precursor.

Sample 3. Surface morphology of $\mathrm{CuO}$ nanopartices recorded at various magnifications through SEM analysis is shown in Figure 4.

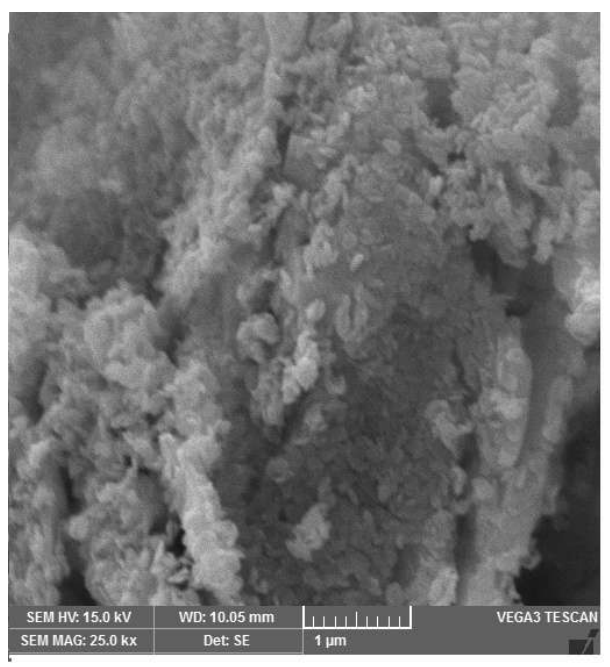

Fig (a)

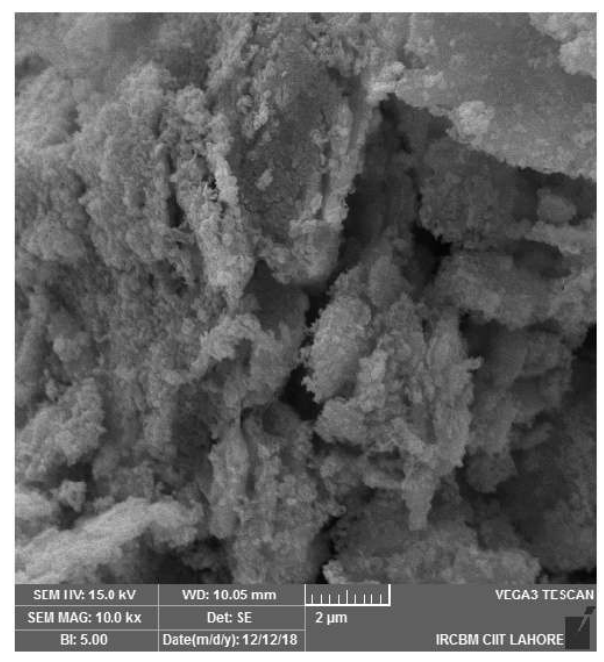

Fig (b)

Figure 4. SEM image $\mathrm{CuO}$ NPs from adipic acid as precursor.

It is clear from above diagram that particles are well defined, shows spherical and identical crystalline structure. It seems that synthesized particles are agglomerated and form a cluster. Particle size in SEM images of all three samples was found in the range of 1-2 $\mu \mathrm{m}$. 


\section{TGA analysis}

The decomposition pattern was recorded from TGA/DSC analysis of synthesized materials. NPs synthesized from malonic acid precursor, succinic acid precursor and adipic acid precursor are labeled as a, b and c, respectively.

TGA and DSC studies of CuO NPs were done in nitrogen atmosphere. The synthesized NPs by using different precursors showed very similar decomposition pattern. For material labeled a, $1^{\text {st }}$ weight loss was recorded between $50{ }^{\circ} \mathrm{C}$ and $160{ }^{\circ} \mathrm{C}$ which may be due to removal of physically absorbed and chemically bonded water with synthesized NPs. The two endothermic DSC peaks around $75{ }^{\circ} \mathrm{C}$ and $170{ }^{\circ} \mathrm{C}$ confirmed the evaporation of water. This weight loss pattern showed good agreement with the TGA results [30,31]. Materials labeled as b and $\mathbf{c}$ showed approximate same pattern in the above mentioned temperature range. In material a, there is another weight loss around $280{ }^{\circ} \mathrm{C}$ which may be ascribed to the loss of the decomposition of few residual impurities along with DSC peak around $310{ }^{\circ} \mathrm{C}$. Materials $\mathbf{b}$ and c also showed same response in this temperature range. After $300{ }^{\circ} \mathrm{C}$ to onward, there is no significant weight loss by increasing temperature in all three samples. This behavior indicated the thermal stabilization of the synthesized $\mathrm{CuO}$ NPs.

\section{Antimicrobial activity of $\mathrm{CuO}-\mathrm{NPS}$}

In latest study in nanotechnology, various metal and metal oxide nanoparticles have been reported as antimicrobial agent [32-40]. Metal nanoparticles containing magnesium oxide [34], copper [38, 40], silver [32-36], iron [41], zinc oxide [42-44], and nickel oxide [45, 46] are exhibit antimicrobial properties. Antimicrobial activity of $\mathrm{CuO}$ nanoparticles synthesized by using different precursors were tested against three gram positive bacterial strains, i.e. S. aureus, B. subtilis, MRSA and three gram-negative strains, i.e. E. coli, S. typhi, and K. pneumoniae by using the agar well diffusion assay method [47]. Results are presented in Table 4.

Table 4. Zone of inhibition of CuO-NPs against pathogenic bacterial strains.

\begin{tabular}{|l|c|c|c|c|c|c|}
\hline \multirow{2}{*}{ Sample } & \multicolumn{5}{|c|}{ Diameter of inhibition zone (mm) } \\
\cline { 2 - 7 } & \multicolumn{3}{|c|}{ Gram Positive } & \multicolumn{3}{c|}{ Gram Negative } \\
\cline { 2 - 7 } & S. aureus & B. subtilis & MRSA & E. coli & K. pneumoniae & S. typhi \\
\hline Sample 1 & $12 \pm 0.11$ & $25 \pm 2.50$ & $5.0 \pm 0.51$ & $20 \pm 0.1$ & $8.0 \pm 0.13$ & $10 \pm 0.55$ \\
\hline Sample 2 & $18 \pm 1.1$ & $22 \pm 0.12$ & $10 \pm 0.33$ & $25 \pm 0.02$ & $10 \pm 0.11$ & $15 \pm 0.12$ \\
\hline Sample 3 $^{\text {a }}$ & $15 \pm .15$ & $20 \pm 0.11$ & $8.0 \pm 0.18$ & $22 \pm 0.41$ & $10 \pm 0.15$ & $12 \pm 0.17$ \\
\hline Standard $^{\mathrm{a}}$ & $30 \pm 0.11$ & $28 \pm 0.21$ & $32 \pm 0.51$ & $29 \pm 0.06$ & $28 \pm 0.17$ & $26 \pm 0.01$ \\
\hline
\end{tabular}

${ }^{\mathrm{a}}$ Ampicillin was used as positive control.

$\mathrm{CuO}-\mathrm{NPs}$ showed good antibacterial activity against selected bacterial strains. NPs found to be more effective against $B$. Subtilis and $S$. aureus and reluctant their growths to a greater extent but these particles were found to be less effective against MRSA. Similarly activity of CuO-NPs was found to be quite promising and encouraging against $E$. coli but less diameter of inhibition zone was noticed in case of $K$. pneumoniae and S. typhi. MIC values in $\mu \mathrm{g} / \mathrm{mL}$ were calculated, comparing it with standard antibacterial (Ampicillin) in concentration $1.0 \mu \mathrm{g} / \mathrm{mL}$ in each plate as positive control. Results are summarized in Table 5 .

The MIC value of sample 1 is maximum, i.e. $35 \mu \mathrm{g}$ for $K$. pneumoniae and minimum, i.e. 15 $\mu \mathrm{g}$ for $B$. Subtilis and E. coli. Similarly, sample 2 surprisingly showed very small MIC value against $E$. coli which is an effectiveness indicator of this sample against this strain. Sample 3 showed higher MIC value, i.e. $40 \mu \mathrm{g}$ against $K$. pneumonia, which indicates the less activity of this sample against concerned bacterial strain. 
Table 5. MIC of CuO-NPs against pathogenic bacterial strains.

\begin{tabular}{|c|c|c|c|c|c|c|}
\hline \multirow{2}{*}{ Sample } & \multicolumn{5}{|c|}{ MIC values against various bacterial strains $(\mu \mathrm{g} / \mathrm{mL})$} \\
\cline { 2 - 7 } & \multicolumn{3}{|c|}{ Gram Positive } & \multicolumn{3}{c|}{ Gram Negative } \\
\cline { 2 - 7 } & S. aureus & B. Subtilis & MRSA & E. coli & K. pneumoniae & S. typhi \\
\hline Sample 1 & 25 & 15 & 30 & 15 & 35 & 25 \\
\hline Sample 2 & 11 & 10 & 25 & 5 & 30 & 15 \\
\hline Sample 3 & 30 & 35 & 25 & 10 & 40 & 10 \\
\hline Standard $^{\text {a }}$ & 7 & 5 & 8 & 9 & 6 & 8 \\
\hline
\end{tabular}

${ }^{a}$ Ampicillin was used as positive control.

It can be concluded that $\mathrm{CuO}$ nanoparticles can inhibit bacterial cell growth and multiplication. This inhibition in growth may be due to the phenomenon in which NPs adhere to cell wall of bacteria and penetrated through cell membrane, which finally leads to cell lysis. This resulted into inhibition of bacterial cell growth and multiplication. As a result, it is highly recommended that use of $\mathrm{CuO}-\mathrm{NPs}$ as an economic alternative anti- bacterial agent especially in treating ectopic infections.

\section{CONCLUSION}

Using a simple and inexpensive wet chemical method, synthesis of copper oxide nanoparticals with size of 1-2 $\mu \mathrm{m}$ has been successfully carried out. FTIR, XRD and SEM results confirmed successful synthesis of CuO-NPs. Powder X-ray analysis showed that NPs synthesized from succinic acid salt precursor have smallest sizes and larger surface area. Remarkable activity against various bacterial strains were exhibited by sample 2 with MIC 10 $\mu \mathrm{g} / \mathrm{mL}$ and zone of inhibition $22 \pm 0.12$ against $B$. Subtilis indicating that these synthesized NPs are good candidates for future therapeutic applications in medical field.

\section{ACKNOWLEDGMENTS}

Authors gratefully acknowledge the Chairman BS and Head of Department, UET Lahore (KSK Campus) to provide lab facility to carry out this research work. We are also thankful to Comsat Institute of Information \& Technology Lahore, Pakistan for assisting us in sample characterization.

\section{REFRENCES}

1. Moreno-Manas, M.; Pleixats, R. Formation of carbon-carbon bonds under catalysis by transition-metal nanoparticles. Acc. Chem. Res. 2003, 36, 638-643.

2. Lanone, S.; Boczkowski, J. Biomedical applications and potential health risks of nanomaterials: Molecular mechanisms. Curr. Mol. Med. 2006, 6, 651-663.

3. Garnett, M.C.; Kallinteri, P. Nanomedicines and nanotoxicology: Some physiological principles. Occup. Med. 2006, 56, 307-311.

4. Hoa, N.D.; An, S.Y.; Dung, N.Q.; Quy, N.V.; Kim, D. Synthesis of p-type semiconducting cupric oxide thin films and their application to hydrogen detection. Sens. Actuators B 2010, 146, 239-244.

5. Wong, L.M.; Chiam, S.Y.; Huang, J.Q.; Wang, S.J.; Pan, J.S.; Chim, W.K. Growth of $\mathrm{Cu}_{2} \mathrm{O}$ on $\mathrm{Ga}$-doped $\mathrm{ZnO}$ and their interface energy alignment for thin film solar cells. $J$. Appl. Phys. 2010, 108, 033702. https://doi.org/10.1063/1.3465445

6. Mebrahtu, C.; Taddesse, A.M.; Goro, G.; Yohannes, T. Natural pigment sensitized solar cells based on $\mathrm{ZnO}-\mathrm{TiO}_{2}-\mathrm{Fe}_{2} \mathrm{O}_{3}$ nanocomposite in quasi-solid state electrolyte system. Bull. Chem. Soc. Ethiop. 2017, 31, 263-279. 
7. Mahalingam, T.; Chitra, J.S.P.; Chu, J.P.; Moon, H.; Kwon, H.J.; Kim, Y.D. Photoelectrochemical solar cell studies on electroplated cuprous oxide thin films. J. Mater. Sci.: Mater. Electron. 2006, 17, 519-523.

8. Fernando, C.A.N.; Bandara, T.M.W.J.; Wethasingha, S.K. $\mathrm{H}_{2}$ evolution from a photoelectrochemical cell with $\mathrm{n}-\mathrm{Cu}_{2} \mathrm{O}$ photoelectrode under visible light irradiation. Sol. Energy Mater. Sol. Cells 2001, 70, 121-129.

9. Ristova, M.; Neskovska, R.; Mireski, V. Chemically deposited electrochromic cuprous oxide films for solar light modulation. Sol. Energy Mater. Sol. Cells 2007, 91, 1361-1365.

10. Wei, B.; Shi, Z.; Xiao, J.; Xu, Y.; Lv, L. In vivo and in vitro antibacterial effect of nanostructured titanium coating incorporated with silver oxide nanoparticles. J. Biomater. Tiss. Eng. 2017, 7, 418-425.

11. Majumder, S.; Neogi, S. Antimicrobial activity of copper oxide nanoparticles coated on cotton fabric and synthesized by one-pot method. Adv. Sci. Eng. Med. 2016, 8, 102-111.

12. Nibret, A.; Yadav, O.P.; Diaz, I.; Taddesse, A.M. Cr-N co-doped ZnO nanoparticles: Synthesis, characterization and photocatalytic activity for degradation of thymol blue. Bull. Chem. Soc. Ethiop. 2015, 29, 247-258.

13. Ehi-Eromosele, C.O.; Olugbuyiro, J.A.O.; Taiwo, O.S.; Bamgboye, O.A.; Ango, C.E. Synthesis and evaluation of the antimicrobial potentials of cobalt doped- and magnesium ferrite spinel nanoparticles. Bull. Chem. Soc. Ethiop. 2018, 32, 451-458.

14. Lisiecki, I.; Pileni, M.P. Syntheses of copper nanoparticles in microemulsion and in reverse micelles. J. Am. Chem. Soc. 1993, 115, 3887-3896.

15. Hajipour, M.J.; Fromm, K.M.; Ashkarran, A.A.; de Aberasturi, D.J.; de Larramendi, I.R.; Rajo, T.; Serpooshan, V.; Parak, W.J.; Mohmoudi, M. Antibacterial properties of nanoparticles. Trends Biotechnol. 2012, 30, 499-511

16. Buckley, J.J.; Gai, P.L.; Lee, A.F.; Olivi, L.; Wilson, K. Silver carbonate nanoparticles stabilised over alumina nanoneedles exhibiting potent antibacterial properties. Chem. Commun. 2008, 18, 4013-4015.

17. Marambio-Jones, C.; Hoek, E.M. A review of the antibacterial effects of silver nanomaterials and potential implications for human health and the environment. $J$. Nanopart. Res. 2010, 12, 1531-1551.

18. Tran, N.; Mir, A.; Mallik, D.; Sinha, A.; Nayar, S.; Webster, T.J. Bactericidal effect of iron oxide nanoparticles on Staphylococcus aureus. Int. J. Nanomed. 2010, 5, 277-283.

19. Lee, C.; Kim, J.Y.; Lee, W.I.; Nelson, K.L. Yoon, J.; Sedlak, D.L. Bactericidal effect of zero-valent iron nanoparticles on Escherichia coli. Environ. Sci. Technol. 2008, 42, $4927-$ 4933.

20. Lara, H.H.; Garza-Treviño, E.N.; Ixtepan-Turrent, L.; Singh, D.K. Silver nanoparticles are broad-spectrum bactericidal and virucidal compounds. J. Nanobiotechnol. 2011, 9, 30. DOI: $10.1186 / 1477-3155-9-30$.

21. Zhao, Y.; Tian, Y.; Cui, Y.; Liu, W.; Ma, W.; Jiang, X. Small molecule-capped gold nanoparticles as potent antibacterial agents that target gramnegative bacteria. J. Am. Chem. Soc. 2010, 132, 12349-12356.

22. Jin, T.; He, Y. Antibacterial activities of magnesium oxide $(\mathrm{MgO})$ nanoparticles against food borne pathogens. J. Nanopart. Res. 2011, 13, 6877-6885.

23. Lellouche, J.; Friedman, A.; Lellouche, J.P.; Gedanken, A.; Banin, E. Improved antibacterial and antibiofilm activity of magnesium fluoride nanoparticles obtained by water-based ultrasound chemistry. Nanomed-Nanotechnol. 2012, 8, 702-711.

24. Besinis, A.; De Peralta, T.; Handy, R.D. The antibacterial effects of silver, titanium dioxide and silica dioxide nanoparticles compared to the dental disinfectant chlorhexidine on Streptococcus mutans using a suite of bioassays. Nanotoxicol. 2014, 8, 1-6. 
25. Espitia, P.J.P.; Soares, N.F.F.; dos Reis Coimbra, J.S.; de Andrade NJ, Cruz, R.S.; Medeiros, E.A.A. Zinc oxide nanoparticles: Synthesis, antimicrobial activity and food packaging applications. Food Bioprocess Technol. 2012, 5, 1447-1464.

26. Karthik, A.D.; Geetha, K. Synthesis of copper precursor, copper and its oxide nanoparticles by green chemical reduction method and its antimicrobial activity. J. Appl. Pharm. 2013, 3, 016-021.

27. Premkumar, T.; Geckeler, K.E. A green approach to fabricate $\mathrm{CuO}$ nanoparticles. J. Phys. Chem. Solids 2006, 67, 1451-1456.

28. Nakamoto, K. Infrared Raman Spectra of Inorganic and Coordination Compounds, 3rd ed., John Wiley and Sons: New York; 1992.

29. Radhakrishnan, A.A.; Beena, B.B. Structural and optical absorption analysis of $\mathrm{CuO}$ nanoparticles. Indian J. Adv. Chem. Sci. 2014, 2, 158-161.

30. Singh, I.; Bedi, R.K. Surfactant-assisted synthesis, characterizations, and room temperature ammonia sensing mechanism of nanocrystalline CuO. Solid State Sci. 2011, 13, 2011-2018.

31. Srivastava, M.; Ojha, A.K.; Chaubey, S.; Sharma, P.K.; Pandey, A.C. J. Alloy Compd. 2010, 494, 275-484.

32. Alt, V.; Bechert, T.; Steinrcke, P.; Wagener, M.; Seidel, P.; Dingeldein, E.; Domann, U.; Schnettler, R. An in vitro assessment of the antibacterial properties and cytotoxicity of nanoparticulate silver bone cement. Biomater. 2004, 25, 4383-4391.

33. Furno, F.; Morley, K.S.; Wong, B.; Sharp, B.L.; Arnold, P.L.; Howdle, S.M.; Bayston, R.; Brown, P.D.; Winship, P.D.; Reid, H. Silver nanoparticles and polymeric medical devices: A newapproach to prevention of infection. J. Antimicrob. Chemother. 2004, 54, 1019-1024.

34. Jeong, S.H.; Yeo, S.Y.; Yi, S.C. The effect of filler particle size on the antibacterial properties of compounded polymer/silver fibers. J. Mater. Sci. 2005, 40, 5407-5411.

35. Chou, W.L.; Yu, D.G.; Yang, M.C. The preparation and characterization of silver-loading cellulose acetate hollow fiber membrane for water treatment. Polym. Adv. Technol. 2005, $16,600-607$.

36. Sambhy, V.; MacBride, M.M.; Peterson, B.R.; Sen, A. Silver bromidenanoparticle/polymer composites: Dual action tunable antimicrobial materials, J. Am. Chem. Soc. 2006, 128, 9798-9808.

37. Stoimenov, P.K.; Klinger, R.L.; Marchin, G.L.; Klabunde, K. Metal oxide nanoparticles as bactericidal agents. Lang. 2002, 18, 6679-6686.

38. Hsiao, M.T.; Chen, S.F.; Shieh, D.B.; Yeh, C.S. One-pot synthesis of hollow Au3Cu1 spherical-like and biomineral botallackite $\mathrm{Cu}-2(\mathrm{OH})(3) \mathrm{Cl}$ flowerlike architectures exhibiting antimicrobial activity. J. Phys. Chem. B 2006, 110, 205-210.

39. Theivasanthi, T.; Alagar, M. Studies of copper nanoparticles effects on micro-organisms. Annals Biol. Res. 2011, 2, 368-373.

40. Morones, J.R.; Elechiguerra, J.L.; Camacho, A.; Holt, K.; Kouri, J.B.; Ramírez, J.T.; Yacaman, M.J. The bactericidal effect of silver nanoparticles. Nanotechnol. 2005, 16, 23462353.

41. Lee, C.; Kim, Y.; Lee, W.I.; Nelson, K.L.; Yoon, J.; Sedlak, D.L. Bactericidal effect of zerovalence iron nanoparticles on Escherichia coli. Environ. Sci. Technol. 2008, 42, 4927-4933.

42. Zvekic, D.; Srdic, V.V.; Karaman, M.A.; Matavulj, M.N. Antimicrobial properties of ZnO nanoparticles incorporated in polyurethane varnish. Proc. Appl. Cer. 2011, 5, 41-45.

43. Rajendran, R.; Bala Kumar, C.; Ahammed, H.A.M.; Jayakumar, S.; Vaideki, K.; Rajesh, E.M. Use of zinc oxide nanoparticles for production of antimicrobial textiles. Int. J. Eng. Sci. Technol. 2010, 2, 202-208.

44. Gondal, M.A.; Dastageer, M.A.; Khalil, A.; Hayat, K.; Yamani, Z.H. Nanostructured ZnO synthesis and its application for effective disinfection Escherichia coli micro organism in water. J. Nanopart. Res. 2011, 133, 423-430. 
45. Wangsaprom, K.; Maensiri, S. Synthesis structural characterization of nickel oxide nanoparticles synthesized by polymerized complexed (PC) method, Proceed in 3rd Int. Nanoelec. Conf. 2010, 1044-1045.

46. Kavitha, T.; Yuvaraj, H. A facile approach to the synthesis of high-quality NiO nanorods: Electrochemical and antibacterial properties. J. Mater. Chem. 2011, 21, 15686-15691.

47. Perez, C.; Paul, M.; Bazerque, P. Antibiotic assay by agar well diffusion method, Acta Biol. Med. Exp. 1990, 15, 113-115. 